\title{
Problematika Liberalisasi Rekrutmen Sumber Daya Manusia Perbankan Syariah di Sampang Madura
}

\author{
Zainal Abidin and Rudy Haryanto \\ STAIN Pamekasan \\ zainal.madura@gmail.com,rudy@stainpamekasan.ac.id
}

\begin{abstract}
The purpose of this study was to describe the problematic of liberalization of Human Resource Recruitment in sharia banking by discussing the recruitment process until the placement of employees in banking, especially in Sampang. This research used descriptive qualitative method with phenomenological approach, data collection technique is done by observation, interview and document study. The results showed that Human Resources involved in banking can be from diverse educational background, not only from sharia banking education or a cognate education, such as economics and business, except health and literature graduated who cannot follow the admission selection. There is no protection against prospective employees from economic and business graduation and sharia banking. The recruitment process is done by the above office with a process that has already passed the standard. Structuring of Human Resources in sharia banking Sampang is based on organizational structure that has been standard with job description that has been arranged so that managers can easily place an employee in Islamic banking at Sampang Madura.
\end{abstract}

Keywords: liberalization recruitment, human resource, sharia banking.

\begin{abstract}
Abstrak
Tujuan dari penelitian ini adalah mendeskripsikan problematika liberalisasi rekruitmen SDM pelaku perbankan syariah dengan mengetangabkan proses rekruitmen sampai pada penempatan karyawan dalam suatu perbankan, khususnyayang terjadiperbankan syariab sampang. Penelitian inimenggunakan metode kualitatif deskriptif dengan pendekatan fenomemologis, teknik pengumpulan data dilakukan dengan observasi, wawancara dan studi dokumen. Hasil penelitian menunjukkan bahwa SDM yang terlibat dalam perbankan bisa dari beragam latar belakang pendidikan, tidak mesti dari pendidikan perbankan syariah atau pendidikan yang serumpun, misalnya ekonomi dan bisnis. Hanya alumni kesehatan dan sastra yang tidak bisa mengikuti seleksi masuk. Tidak ada proteksi terhadap calon karyawan dari alumni ekonomi dan bisnis maupun perbankan syariah. Proses perekrutan dilakukan oleb kantor di atasnya dengan proses yang sudab melalui standar baku. penataan SDM di perbankan syariah sampang adalab berdasarkan struktur organisasi yang sudab baku dengan job deskripsi yang sudah tertata dan manajer bisa dengan mudah menempatkan seorang karyawan di perbankan syariab Sampang Madura.
\end{abstract}

Kata Kunci: liberalisasi rekrutmen, sumber daya manusia, perbankan syariah.

Permalink/DOI:http://dx.doi.org/10.18326/infs13.v11i2.373-390 


\section{Pendahuluan}

Kesesuaian antara latar belakang pendidikan seseorang dengan profesinya merupakan sebuah keniscayaan. Misalnya Untuk bisa menjadi seorang guru/pendidik maka latar belakang pendidikannya adalah sarjana pendidikan/keguruan/tarbiyah. Sarjana hukum/ syariah mempunyai kesempatan untuk bisa menjadi seorang hakim. Seorang dokter haruslah sarjana kedokteran. Begitulah rumus sederhana di dunia kerja, sehingga ketika ada profesi yang diisi oleh orang yang latar belakang pendidikannya tidak sesuai maka orang itu dikatakan tidak profesional. (http://www.landasanteori. com/2015/10/pengertian-profesionalisme-kerja.html).

Namun realita seperti itu tidak terjadi didunia perbankan. Dari survey singkat peneliti terhadap latar belakang pendidikan bankir atau karyawan perbankan di Madura ditemukan beberapa latar belakang pendidikan yang jauh panggang dari api, walalupun juga ditemukan yang masih serumpun seperti ekonomi dan lain sebagianya.

\section{Tabel 1}

Latar Belakang Pendidikan dan Posisi Karyawan

\begin{tabular}{lll}
\hline No & $\begin{array}{l}\text { Latar Belakang } \\
\text { Pendidikan }\end{array}$ & Posisi Di Perbankan \\
\hline 1 & MIPA & CS BRI Syariah Pamekasan \\
2 & HUKUM & Teller BSM Pamekasan \\
3 & HUKUM & $\begin{array}{l}\text { Ketua BRI Syariah } \\
\text { Bangkalan } \\
4\end{array}$ \\
& TEHNIK & Manajer BSM Sampang \\
\hline
\end{tabular}

Sumber: Observasi di perbankan syariah di madura tabun 2017.

Senada dengan fenomena di atas, dalam konteks nasional sudah menjadi rahasia umum bahwa pegawai bank/ bankir di Bank Indonesia (BI) mayoritas adalah alaumni IPB Bogor sehingga IPB yang semula adalah Institut Pertanian Bogor diplesetkan menjadi Institut Perbankan Bogor karena mayoritas karyawan di BI adalah alumni IPB Bogor. 
Dalam sebuah diskusi pemetaan profesi perbankan yang pernah diikuti peneliti pernah dipertanyakan bagaimana fenomena tersebut tentang alumni IPB yang bisa mendominasi perbankan termasuk Bank Indonesia. Dalam ranah itu pihak BI menjawab bahwa salah satu reasoning terhadap fenomena tersebut adalah kenyataan bahwa alumni IPB bogor dengan latar belkang pendidikan pertaniannya ternyata setelah diamati sekitar 3-5 tahun jauh lebih hebat performance-nya sebagai bankir dibandingkan dengan alumni yang lain termasuk dengan alumni perbankan sekalipun. Hal itu dikarenakan salah satu kapasitas alumni IPB adalah mampu mengingat beberapa hukum dan ketentuan tentang akar, macam-macam akar dan lain sebagainya yang berhubungan dengan detail-detail pepohonan sebagai salah satu kapasitas latar belakang pendidikannya. Kapasitas tersebut ketika terjun diperbankan sangat mampu mengendalikan sebuah bank sampai kepada informasi yang sangat detail. Berdasarkan bukti empiris inilah maka alumni IPB dianggap dan dinilai berkompeten dalam industri perbankan walaupun ia tidak pernah mengenyam ilmu perbankan (Dokumentasi dari kegiatan di UIN Malang tahun 2014).

Secara konseptual bank adalah lembaga perantara keuangan (Muhammad, 2016:1). Sehingga bank identik dengan uang sebagai alat yang utama dalam sebuah usaha bisnis/perdagangan. Sedangkan Bank Syariah adalah Bank yang beroperasi sesuai dengan prinsip-prinsip syariah (Muhammad, 2016:1). Oleh karena itu merupakan sebuah keniscayaan bahwa SDM perbankan syariah harus memahami prinsip-prinsip syariah dalam masalah perbankan atau yang dikenal dengan muamalah.

Perbankan termasuk pula perbankan syariah merupakan sebuah usaha yang bergerak dalam keuangan atau lebih sederhananya adalah sebuah bisnis bahkan sebuah beavy industry in the bussiness (industri yang berat dalam sebuah bisnis). Untuk itu, dalam menjalankan bisnis perbankan, di butuhkan profesionalisme dari tenaga kerja yang ada di dalamnya. 
SDM merupakan kunci utama bagi pengembangan usaha bisnis Islam ke depan, sehingga upaya mempersiapkan kualifikasi SDM yang profesional dan mempunyai komitmen moral kepada keyakinannya akan melahirkan perusahaan bisnis Islam yang berkembang dan maju di masa yang akan dating (Muhammad, 2016:750).

Oleh karena itu realita yang ada dalam rekrutmen SDM perbankan syariah termasuk di Madura layak untuk di kaji. Hal itu dikarenakan terdapat sebuah problematika yang laten yaitu betapa liberal/bebasnya semua orang sebagai SDM dengan latar belakang pendidikan yang beragam dan heterogen bisa tersaring dalam proses rekrutmen SDM perbankan syariah. Padahal perbankan harus dikelola oleh orang yang profesional tentang perbankan yang salah satu indikatornya mempunyai latar belakang pendidikan perbankan atau disiplin ilmu yang serumpun dengan perbankan.

Sampang merupakan salah satu kabupaten di antara 3 kabupaten lainnya di madura. Ada dua pertimbangan memilih sampang sebagai pertimbangan unuk di jadikan sampel. Pertama, Kabupaten sampang merupakan kabupaten yang memiliki prestasi ekonomi yang berada dipaling bawah dibandinkan dengan tiga kabupaten lainnya di Madura. Kedua, di Kabupaten sampang terdapat BPD Jatim Syariah sebagai satu-satnya BPD Jatim Syariah di Madura.

Penelitian ini tentunya akan mempunyai sebuah signifikansi bagi pemetaan perkembangan ekonomi Islam di Madura terutama dalam ranah perbankan syariah. Secara praktis penelitian ini berusaha membedah semua celah profesi yang bisa diisi oleh alumni perbankan syariah, sehingga sejak dini ia harus sudah mempersiakan diri agar sesuai dengan tuntutan dan permintaan pasar. Kesadaran akan hal itu akan membangunkan sebuah semangat untuk menjadi spirit bagaimana menjadi SDM yang profesional dan berkualitas.

Di samping itu dalam ranah teoritis penelitian ini akan menjadi sebuah diskursus awal pemetaan kompetensi untuk mempersiapakan alumni yang profesional dalam mencetak SDM Bankir atau karyawan perbankan syariah. 


\section{Kerangka Teoritik}

Konsep Ekonomi Sumber Daya Manusia

Ekonomi sumber daya manusia (ESDM) adalah penerapan ekonomi terhadap masalah sumber daya manusia. Sumber daya manusia bisa dipahami sebagai usaha kerja atau jasa yang dapat diberikan dalam proses produksi. Dalam hal ini SDM adalah serminan kualitas usaha yang diusahakan oleh seseorang untuk menghasilkan barang atau jasa. Pemahaman lain terhadap SDM adalah manusia yang mampu bekerja sehingga bisa memberikan kontribusi barang dan jasa, sehingga ia mampu bernilai secara ekonomis, sehingga ukurannya manusia yang mampu bekerja, mislanya manusia dalam usia kerja (Nawawi, 2013:460-461).

1. Teori ekonomi sumber daya manusia

Ada beberapa teori tentang SDM dari beberapa tokoh yaitu, Adam Smith, menyatakan bahwa manusia adalah faktor produksi utama yang menentkan kemakmuran suatu bangsa. Tanpa manusia faktor produksi yang lain tidak akan ada artinya (Nawawi, 2013:466). Maltus, menyatakan bahwa perkembangan manusia jauh lebih cepat dari kemampuan produksi hasil pertanian untuk mencukupi kebutuhannya (Nawawi, 2013:467).

2. Manajemen SDM Syariah

Sebagai penyeimbang dan konsep perbandingan maka perlu dihadirkan konsep manajemen SDM syariah. Biasanya SDM dalam konteks syariah dikenal dengan konsep Sumber Daya Insani (SDI).

3. Manajemen SDM perbankan syariah

Manajemen SDM di perbankan syariah diperlukan untuk melihat bagaimana sebuah potensi SDM dikelola di sebuah unit usaha bisnis keuangan syariah seperti perbankan syriah. Disamping ada persamaan pasti terdapat perbedaan didalamnya karena perbankan syariah harus berlandaskan nilai-nilai syariah. Sebagai contoh adalah pemetaan tipe SDM ekonom syariah. 
Ada beberapa tipe SDM ekonomi syariah,yaitu: Tipe pertama yaitu orang yang mempunyi kompetensi ilmu shariah dan memahami ilmu ekonomi bisnis. Pakar tipe pertama ini diproyeksikan akan memberikan sumbangan dalam ranah normatif dengan mencari prinsip-prisip shariah Islam dalam ekonomi bisnis. Tipe kedua orang yang paham ilmu ekonomi bisnis yang paham shariah. Tipe kedua ini diproyeksikan bisa memberikan masukan berupa analisis ilmu ekonomi terhadap pelaksanaan normatif dari ekonomi Islam. Tipe ketiga adalah orang yang sama-sama paham antara ilmu ekonomi bisnis dan ilmu shariah. Inilah tipe yang ideal untuk mengelola bisnis shariah. Namun sangat jarang sekali orang yang bisa memenuhi kualifikasi seperti tipe ketiga ini (Nawawi, 2013:741-743).

Dari beberapa teori di atas maka bisa dipetakan dengan jelas bagaimana problema liberalisasi yang terjadi dalam rekrutmen SDM perbankan syariah di Madura sesuai dengan topik penelitian di atas.

\section{Metode Penelitian}

Penelitian ini menggunakan metode kualitatif deskriptif dengan pendekatan fenomemologis. Penelitian ini mempunyai kecenderungan untuk mengungkap dan memformulasikan data lapangan dalam bentuk narasi verbal yang utuh dan mendeskripsikan realitas aslinya kemudian data itu bisa dianalisis. Penelitian ini menekankan pada interpretasi dan analisis emic (Saifuddin, 2005:92), berupa ungkapan dan simbol yang ada di lapangan. Demikian juga penelitian ini berusaha menjawab dan mengungkap tentang bebasnya/liberalnya seseorang dengan latar belakang pendidikan apa saja bisa masuk mendaftar dan bahkan lolos menjadi seorang bankir. Data-data tersebut tentunya sebuah pola yang cocok didekati dengan metode penelitian kualitatif (Martono, 2015:212). Teknik pengumpulan data dilakukan dengan observasi atau pengamatan langsung, wawancara mendalam dan studi dokumen.

Sumber Data primer dalam penelitian ini yaitu para direktur dan manajer perbankan syariah serta bagian yang berhubungan dengan SDM perbankan syariah di Sampang Madura yang dapat 
dipetakan yaitu BSM Syariah Cabang Sampang dan BPD Jatim Syariah Sampang.

Sedangkan sumber sekunder adalah phak-pihak yang berhubungan dengan rekrutman SDM Perbankan Syariah baik dari kalangan ahli dan praktisi di Madura baik meliputi akademisi dan praktisi yang memahami tentang rekrutmen tenaga SDM yang ada di perbankan syariah di Sampang Madura.

Dalam menganalisis penelitian ini menggunakan petunjuk dari Huberman dan B. Miles, yaitu: (K. Denzin dan S. Linclon, 1984:492) Pertama, reduksi data dengan menyeleksi semua data dengan menyederhanakan dan memotong data-data yang ada sesuai dengan tema-tema kecil yang sesuai dengan topik penelitian. Kedua, kategorisasi terhadap data yang sudah direduksi sesuai dengan topik penelitian yaitu dinamika pemikiran kyai tentang ekonomi. Ketiga, verifikasi untuk melakukan simpulan yang merupakan interpretasi peneliti terhadap data.

Untuk mengecek apakah data yang didapatkan valid maka diperlukan keabsahan terhadap temuan penelitian dengan melakukan beberapa hal yaitu, a) Menambah dan memperpanjang intensitas kehadiran dalam melakukan penelitian. b) Observasi yang diperdalam terhadap lapangan penelitian. c) Triangulasi yaitu dengan menggunakan beberapa sumber data. Baik triangulasi antar informan, informan dengan data, pendapat orang lain. Hal itu bisa dilakukan dengan melakukan wawancara lebih dari satu orang informanan sehingga hasil penelitian merupakan realitas bukan suatu kebetulan (by chance).

\section{Analisis}

\section{Hubungan SDM dan Usaba Bisnis}

Beberapa konsep yang berhubungan dengan SDM dan perbankan ketika dilihat sebagai sebuah usaha bisnis dalam ranah keuangan, yaitu:

1. Model Manajemen SDM dalam sebuah usaha Bisnis

Karyawan merupakan manusia, sehingga melihat seorang 
karyawan hendaknya bukan hanya sebagai faktor produksi saja, melainkan ada nilai lebih dari sekedar tenaga kerja. Beberapa corak dalam memahami karyawan untuk mencapai sebuah tujuan yang ditetapkan dalam sebuah organisasi bisnis, yaitu: (Nawawi, 2011:728-729) a) Karyawan merupakan sebuah investasi. Jika sebuah investasi dikelola dengan baik dan benar maka dalam jangka panjang akan memberikan benefit yang cukup baik. b) Karyawan hendaknya dilayani dan dipuaskan baik scara lahiriyah maupun batiniyah. Oleh karena itu manajer harus mengusahakan program yang mengarah pada arah yang berorientasi menciptakan kepuasan bagi karyawan. Jika karyawan puas maka ia bukan hanya merasa sebagai karyawan tetapi akan timbul rasa memiliki terhadap perusahaan. Pada akhirnya mereka akan bekerja sepenuh hati dan memberikan kemampuan terbaiknya bagi perusahaan, hal itu bisa dicapai karena mereka merasa memiliki terhadap perusahaan bukan hanya pekerja saja. Oleh karena itu ia akan mempunyai prestasi yang bisa diharapakan yang pada akhirnya akan meningkatkan produktivitas perusahaan. c) Karyawan hendaknya dirangsang untuk terus meningkatkan keahlian dan kemauannya. Dalam menunjang agar perusahaan terus berkembang maka karyawan harus selalu di up grade skillnya. Mengadakan DIKLAT yang berorientasi kepada pengembangan perusahaan merupakan sebuah keniscayaan. Hal itu juga dipengaruhi semakin besar dan kompleksnya tantangan yang akan dihadapi oleh perusahaan dari masa ke masa. d) Harus ada keseimbangan antara hak dan kewajiban bagi karyawan. Keseimbangan inilah sebagai titik tolak dari maju mundurnya sebuah perusahaan. e) Pemberian reward bagi prestasi yang dicapai oleh karyawan merupakan sebuah pendekatan yang perlu dilakukan untuk semakin meningkatkan dan memacu prestasi karyawan. Reward tidak harus berupa materi, penghargaan berupa non materipun sangat diapresiasi oleh karyawan. Di samping rewardsterhadap karyawan yang berprestasi maka punishment bagi karyawan yang tidak konsisten merupakan sebuah keniscayaan yang harus ditradisikan untuk menilai sebuah prestasi karyawan. 
Seorang manajer sebagai ujung tombak dan juga pelaku bisnis maka harus dibekali dengan skill yang mumpuni. Ada beberapa skill yang harus dipahami dan dimiliki oleh seorang manajer, yaitu (Nawawi, 2011:729-730) a) Conceptual skill yaitu kemampuan untuk mengintegrasikan seluruh potensi yang ada dalam perusahaan; b) Human skill yaitu kemampuan memahami manusia lain. Hal itu dapat diaplikasikan dengan memahami, memotivasi serta bisa mengapresiasi orang lain agar berusaha bersama-sama dan mempunyai tujuan untuk mengejar sasaran perusahaan; c) Administrative skill yaitu mengikuti segala prosedur manjemen mulai perencanaan, pengorganisasian, aktualisasi sekaligus pengontrolan. Menciptakan prosedur dan mentaati secara konsisten aturan main yang sudah disepakati sehingga semua kebijakan yang diambil berdasarkan aturan main yang jelas; d) Technikal skill yaitu kemampuan secara teknis seprti teknik pelaporan keuangan, teknik pembukuan dan teknik lain yang diperlukan. Hal itu akan memberikan pemahaman yang leih jelas dalam menjalankan roda perusahaan.

Pemikiran yang holistic dan integral menjadi sebuh keharusan bagi manajer dalam level top sehingga keputusan yang akan diambil bersifat strategic dan demi kepentingan jauh ke depan, menyangkut hal-hal yang fundamental dan keputusan itu mempunyai dampak yang sistemik terhadap perusahaan (Ismail Nawawi, 2011:733-734). Sebaliknya manajer dalam level rendahan, keputusan yang diambil harus bersifat taktis dalam mencapai tujuan bahkan lebih teknikal dan operasional yang hanya berdampak secara mikro dalam bidang pekerjaannya. Semua level dalam manajemen harus diintegrasikan dan direncanakan sedemikian hingga untuk mencapai tujuan perusahan yang telah dicanangkan, (Ismail Nawawi, 2011:735)

\section{Kompetensi SDM Bisnis dalam Konteks Syariah}

Produktivitas sebuah usaha bisnis dipengaruhi oleh dua hal yaitu kredibilitas dan profesionalitas. Kredibilitas dapat dipahami sebagai sebuah nilai yang ideal yang akan terwujud 
dalam rasa percaya dari orang terhadap seseorang atau sebuah lembaga. Kredibilitas dapat dideteksi dalam beberapa hal, yaitu (Nawawi, 2011:739) a) Kejujuran; b) Mampu menjadikan win-win solution; c) Ketaatan terhadap legal formal; d) Transparansi; e) Kearifan dalam meyelesaikan masalah; f) Kesehatan perusahaan; g) Perkembangan sebuah usaha.

Adapun yang dimaksud dengan profesionalitas adalah suatu nilai praktis yang bisa ditemukan dalam kehandalan di dalam mengelola perusahaan dengan cekat dalam melaksanakan semua agenda kegiatan.Profesional tidak hanya terlihat dari performance yang bagus namun dapat dilihat dari kerja nyata yang tampak sebagai hasil dari sebuah kegiatan usaha. Aspek profesionalitas bisa dilihat dari beberapa aspek, yaitu: (Nawawi, 2011:739-740) a) Kerapian pengelolaan bisnis; b) Kesesuian struktur dan keorganisasian perusahaan; c) Keahlian dalam menjalankan usaha; d) Adanya sisetem mekasnisme kerja; e) Kesigapan dalam menangani masalah; f) Adanya sumber daya baik manajer dan karyawan yang berkualitas; g) Adanya sarana dan prasarana yang mendukung kegiatan perusahaan.

Berdasarkan asas kredibilitas dan profesionalitas maka untuk melaksanakan tujuan organisasi diperlukan beberapa perangkat, yaitu: (Nawawi, 2011:743-744) a) Human ware atau diistilahkan perangkat manusia. Human ware merupakan seluruh sumber daya manusia yang ada di dalam perusahaan disemua level baik pemilik, direktur, pengelola sampai pekerja. Semua SDM harus mumpuni dalam bidang kualitas, kuantitas dan terpuji dalam ranah kepribadian. Kalau dalam Islam diistilahkan sebagai insan al-kamil (mendekati kesempurnaan); b) Hard ware atau perangkat keras yaitu alat-alat produksi dan serangkaian alat-alat fisik yang menjadi sarana dan prasarana dari sebuah aktivitas perusahaan; c) Soft ware atau perangkat lunak yaitu semua hal yang meliputi non fisik seperti pembagian tata kerja, etika perusahaan, wewenang dan tanggung jawab semua level dan semua perangkat yang mendukung terciptanya produksi dalam setiap perusahaan. 
Sedangkan dalam ranah pengelolaan bisnis syariah dibutuhkan beberapa kriteria SDM sebagai berikut: (Nawawi, 2011:744-745) a) Tipe pertama yaitu orang yang mempunyai kompetensi ilmu syariah dan memahami ilmu ekonomi bisnis. Pakar tipe pertama ini diproyeksikan akan memberikan sumbangan dalam ranah normatif dengan mencari prinsipprisip syariah Islam dalam ekonomi bisnis. Kontribusi itu diharapkan berupa pikiran yang praktis yang bisa menjawab semua problematika yang hadir dalam dinamika perusahaan; b) Tipe kedua orang yang mempunyai kompetensi ilmu ekonomi bisnis yang paham syariah. Tipe kedua ini diproyeksikan bisa memberikan masukan berupa analisis ilmu ekonomi terhadap pelaksanaan normatif dari ekonomi Islam; c) Tipe ketiga adalah orang yang sama-sama paham (Kompeten) antara ilmu ekonomi bisnis dan ilmu syariah. Inilah tipe yang ideal untuk mengelola bisnis syariah. Namun sangat jarang sekali orang yang bisa memenuhi kualifikasi seperti tipe ketiga ini.

Ketiga tipe yang ada ini diharapkan akan bisa terus menumbuh kembangkan kemampuannya dalam melaksanakan usaha bisnis yang berbasis syariah. Hal itu dengan cara memperhatikan dengan sungguh statemen tentang ekonomi bisnis yang berasal dari sumber dasar Islam yaitu Al Qur'an dan Al Hadith (Ismail Nawawi, 2011:741-743).

Berdasarkan tuntunan syariah maka diharapkan manajemen yang berlangsung akan mempunyai manajemen yang berorientasi kepada konsep ibsan dalam normatif syariah. Manajemen yang berbasis ihsan itu dapat dicirikan sebagai berikut: pertama, sederhana dalam aturan sehingga tercipta kemudahan. Birokrasi yang simple, sederhana dan mudah akan menjadikan manajemen mudah direncanakan, mudah dijalankan dan mudah dikontrol. Kedua, kecepatan dalam pelaksanaan sehingga bisa memuaskan semua orang yang berkepentingan.Ketiga profesional didalam melaksanakan, dan profesional inilah merupakan kunci dari sebuah pelaksanaan manajemen. 
Proyek yang bisa diagendakan untuk mencetak manajer dan manajemen yang berbasis syariah adalah: (Nawawi, 2011:748749) a) Pemahaman tentang sistem lembaga bisnis syariah baik dalam skala mikro dan makro. Mikro meliputi teknis manajemen dan produksi barang dan jasa sebagai sebuah individu atau lembaga usaha bisnis. Sedangkan makro sebagai sebuah sistem yang strategis karena ikut menentukan stabilitas ekonomi sebuah Negara; b) Pemahaman tentang penerapan konsep syariah baik dalam ranah mengembangkan produk, landasan moral dan etika yang menjadi role of game dari sebuah bisnis; c) Pemahaman stakeholder kepada bisnis usaha Islam sehingga diharapkan ada sebuah komitmen dan integritas terhadap konsep syariah khususnya dalam usaha bisnis; d) Peningkatan teknik secara individual baik melalui DIKLAT dan lain sebagainya tentang kompetensi yang berkaitan dengan usaha bisnis seperti DIKLAT entepreneurship berbasis syariah.

\section{Proses Rekrutmen Karyawan di Perbankan Syariab di Sampang Madura}

Proses rekrutmen ada dua model, Pertama, dilakukan oleh Regional Officer (RO) 5 jawa 2 yang berada di atas kantor BSM cape sampang untuk level staf dan atau profesional. Kedua, rekrutmen oleh pusat untuk level Officer Development Program (ODP). namun kedua model tersebut tidak dilakukan oleh perbankan syariah sampang akan tetapi oleh kantor di atasnya. di BSM oleh RO 5 Jawa 2 di BSM surabaya, sedangkan di bank jatim oleh Bank Jatim Surabaya. Adapaun prosesnya sudah melalui standar baku yang sudah ditetapkan. proses yang dilakukan seseuai dengan SOP yang sudah disepakati dimulai dari seleksi administrasi dampai dengan medical check up. Namun ada yang berbeda yaitu adanya test kemampuan membaca Al Qur'an. Hal itu sebagai pebeda antara karyawan Bank syariah dengan lainnya.

Dari standar itu bisa dipahami tidak ada proteksi terhadap calon karyawan dari alumni ekonomi dan bisnis serta ekonomi dan perbankan syariah untuk bisa direkrut disebuah posisi khusus. Hanya alumni kesehatan dan sastra yang tidak bisa mengikuti 
seleksi. Hal ini bisa dipahami karena dunia perbankan adalah dunia bisnis keuangan yang nota bene berhubungan dan melayani semua segmentasi kehidupan, sehingga karyawan didalamnya juga bisa dimasuki oleh semua orang dengan latar belakang yang beragam. Syaratnya adalah lolos seleksi dan pembinaan yang cukup terpercaya dari pihak perbankan karena disamping dilakukan secara accaountable juga melibatkan profesional pihak ketiga serta tes yang berlapis sehingga out put karyawan yang dihasilkan akan mempunyai kualitas yang bisa dipercaya

Pelamar akan melewati Proses seleksi karyawan tiga kali wawancara, yakni wawancara pendahuluan yang dilakukan oleh GSA, wawancara kedua yang dilakukan oleh service manager atau marketingmanager, dan wawancara akhir dengan kepala cabang. Dan calon karyawan baru akan mengikuti tes psikotes yang dilakukan oleh lembaga psikotes luar yang telah bekerjasama dengan perbankan syariah.

Perbankan syariah sampang dalam proses seleksi karyawan mengikuti teori yang ada dalam buku Kasmir Manajemen Perbankan, yakni calon karyawan akan melewati tiga kali proses wawancara. Diantaranya: 1) wawancara pendahuluan, wawancara pendahuluan ini dilaksanakan pada jabatan tertentu seperti teller atau customerservice untuk mengetahui tinggi badan, bentuk tubuh, atau cara pelamar dalam mengemukakan pendapat. 2) Wawancara kedua, wawancara ini dilaksanakan untuk mengetahui bagaimana pelamar menghadapi masalah dan memecahkan masalah. 3) Wawancara akhir/wawancara atasan langsung, wawancara ini dilakukan oleh atasan langsung untuk dapat berbicara langsung mengetahui perilaku dan kemampuan pelamar.

Memang dalam buku Manajemen Perbankan oleh Kasmir, disebutkan bahwa dalam proses seleksi, wawancara awal bisa saja tidak dilaksanakan karena wawancara awal digunakan untuk jabatan teller atau customer service. Bank Syariah sampang melaksanakan wawancara awal karena proses seleksi karyawan yang dilakukan melalui rekrutmen eksternal adalah untuk posisi jabatan frontlineryakni telleratau customer service, itulah mengapa di BankSyariah dalam proses seleksinya melakukan tahapan wawancara awal/wawancara pendahuluan. 
Dengan tiga kali proses wawancara tersebut, akan mendapatkan keputusan akhir yang memuaskan. Karena dalam setiap wawancara yang dilakukan memiliki penilaian tersendiri. Terlihat jelas sisi selektifitas dalam proses seleksi karyawan di Bank Syariah sampang. Juga dengan tiga kali proses wawancara tersebut kompetensi dasar dari calon karyawan akan lebih jelas terlihat.

Sementara untuk tes psikotes, Kasmir menyebutkan bahwa tes psikotes adalah bagian dari tes tertulis. Dalam praktiknya di Bank Syariah sampang tidak demikian, terlihat adanya pemisahan antara tes tertulis dengan tes psikotes. Tes psikotes dilakukan oleh lembaga psikotes yang sudah bekerjasama dengan Bank Syariah yang ada disampang. Lembaga psikotes tersebut melakukan penilaian berdasarkan kriteria penilaian yang telah ditetapkan oleh Kantor Pusat. Hal ini dilakukan supaya memudahkan untuk mendapatkan karyawan terbaik dalam proses seleksinya.

Berdasarkan aspek untung rugi, terlihat jelas bahwa ada biaya khusus yang dikeluarkan oleh pihak Bank Syariah disampang dalam melakukan tes psikotes, namun jika bekerjasama dengan lembaga psikotes luar yang lebih profesional maka peluang mendapatkan karyawan yang terbaik tidak terlalu sulit, dan hal ini menutupi proses rekrutmen yang tidak terbuka melalui iklan, sehingga meskipun proses rekrutmen sepertinya ada kekurangan tapi dengan proses seleksi yang sangat ketat dan dengan melalui beberapa tahapan tersebut, maka karyawan dengan kualitas terbaik dapat ditemukan.

Melihat dari aspek syariah, proses seleksi yang dilakukan oleh Bank Syariah disampang juga menerapkan seleksi syariah. Ada beberapa alat yang digunakan dalam seleksi syariah, yakni: 1) analisis syariah aplikasi lamaran, 2) tes tertulis wawasan syariah; 3) wawancara syariah; 4) rekomendasi syariah (Fahmi, 2004:166-172). Alat-alat seleksi syariah yang diterapkan terlihat pada tes wawasan syariah yang termuat dalam soal-soal tes tertulis dan wawancara syariah yang digabung dalam tiga tahap wawancara dalam proses seleksi karyawan. Meskipun hanya sebagian kecil dari banyaknya pertanyaan dalam tes tertulis yang memuat materi syariah tetapi setidaknya hal-hal dasar mengenai perbankan syariah telahdimuat dalam pertanyaan tes tertulis. 
Ada hal yang menarik dalam selekasi di atas itu adanya kemampuan memahami Al Qur'an dan hukum syariah dalam maslah perbankan. Mungkin inilah kelebihan yang bisa diasah oleh karyawan dengan background ekonomi dan bisnis, ekonomi dan perbankan syariah.

Relasi perguruan tinggi dan perbankan memang perlu dibangun berbasis pada kerjasama yang riil dan kongkret untuk mendukung dan memberi manfaat bagi misi kedua lembaga. Perguruan Tinggi melaksanakan Tri Dharma dan perbankan melaksanakan bisnisnya. Sebuah kerjasama yang berasas simbiosis mutualisme bisa dicarikan untuk memberikan afirmasi bagi kedua belah pihak ditengan liberalnya rekrutmen karyawan perbankan syariah termasuk di sampang madura.

\section{Pemetaan Manajemen SDM Perbankan Syariab di Sampang Madura}

Proses selekasi karyawan di perbankan syariah di sampang madura memang dilakukan kantor di atasnya, namun karyawan hasil rekrutmen tetap ditempatkan di perbankan syariah sampang madura, sehingga penataannya dilakukan oleh perbankan syariah.

Setelah mendapatkan karyawan yang ada maka penataan SDM di perbankan syariah sampang adalah berdasarkan struktur organisasi yang sudah baku dengan job deskripsi yang sudah tertata dengan baik, dengan rekaman rekrutmen karyawan yang cukup panjang maka manajer bisa dengan mudah menempatkan seorang karyawan di perbankan syariah sampang madura. Posisi di kantor cabang memang tidak selengkap yang ada dipusat maupun regional officer sehingga hal itu mempermudah menematkan seseorang disebuah posisi tertentu.

Dari analisis yang ada ternyata latar belakang seorang karyawan tidak berpengaruh signifikan terhadap posisi di karyawan bank syariah. Karyawan akan dilihat pada kecendrungannya, walaupun ada juga yang alumni ekonomi dan bisnis namun banyak yang alumni teknik dan pertanian. 
Hal itu bisa dipahami karena dunia perbankan adalah dunia bisnis yang segmentasinya seluas watak dan karakter serta kompetensi manusia. Oleh karena itu pihak perbankan perlu menangkap semua potensi yang ada, apalagi hana dikantor cabng yang posisi dan jumlah karyawan yag dibutuhkan terbatas.

Tidak ada proteksi apalagi spesialisasi bagi alumni ekonomi, akuntansi dan perbankan sendiri di kantor cabang. Walaupun jika dikantor pusat dan regional officer masih dimungkinkan ada posisi tertentu bagi accounting dan perikatan bagi alumni hukum.

Inilah gray area dunia perbankan yang tetap menjadi misteri yang hanya bisa dipahami jika masuk kedalam ranah realitas dunia perbankan syariah. Memang sudah ada usaha yang cukup signifkan bagi perbankan syariah, diaman ada usaha untuk mencari karyawan berkualitas di kampus yang menggelar ekonomi dan bisnis serta perbankan syariah. Hal itu memang terbatas bagi kampus-kampus yang cukup punya nama dan kampus tersebut punya hubungan emosional berupa kerjasama bisnis yang riil dengan perbankan syariah.

Hanya kerjasamayang riilyangbersifatsaling menguntungkan akan menjadi jalur sutra bagi alumni perbankan, ekonomi dan bisnis islam agar mempunai jalur khusus dan afirmasi dari perbankan termasuk perbankan syariah. Kerjasama riil inilah sebetulnya yang dibutuhkan dalam dunia bisnis. Jika kerjasama ini merupakan sesuatu syarat agar bisa meningkatkan mutu pendidikan tinggi maka hal itu tidak bisa dianggap sebelah mata.

Kerjasama yang serius dengan dunia perbankan perlu dilakukan secara serius mulai dari perencanaan sampai implementasinya sehingga mendatangkan manfaat bagi keduanya. Pihak perbankan dapat menjalankan misi bisnis keuangannya dan perguruan tinggi bisa melaksanakan misi tridharmanya.

\section{Kesimpulan}

Proses rekrutmen tidak dilakukan oleh perbankan syariah sampang akan tetapi oleh kantor di atasnya. Adapaun prosesnya sudah melalui standar baku yang sudh ditetapkan. Dari standar itu bisa dipahami tidak ada proteksi terhadap calon karyawan dari 
alumni ekonomi dan bisnis dan perbankan syariah untuk bisa direkrut disebuah posisi khusus, hanya alumni kesehatan dan sastra yang tidak bisa mengikuti seleksi. Hal itu bisa dipahami karena dunia perbankan adalah dunia bisnis keuangan yang nota bene berhubungan dan melayani semua segmentasi kehidupan, sehingga karyawan didalamnya juga bisa dimasuki oleh semua orang dengan latar belakang yang beragam. Syaratnya adalah lolos seleksi dan pembinaan yang cukup terpercaya dari pihak perbankan karena disamping dilakukan secara accaountable juga melibatkan profesional pihak ketiga serta tes yang berlapis sehingga out put karyawan yang dihasilkan akan mempunyai kualitas yang bisa dipercaya.

Relasi perguruan tinggi dan perbankan memang perlu dibangun berbasis pada kerjasama yang riil dan kongkret untuk mendukung dan memberi manfaat bagi misi kedua lembaga. Perguruan Tinggi melaksanakan tri dharma dan perbankan melaksanakan bisnisnya. Sebuah kerjasama yang berasas simbiosis mutualisme bisa dicarikan untuk memberikan afirmasi bagi kedua belah pihak ditengan liberalnya rekrutmen karyawan perbankan syariah termasuk di sampang madura.

Setelah mendapatkan karyawan yang ada maka penataan SDM di perbankan syariah sampang adalah berdasarkan struktur organisasi yang sudah baku dengan job deskripsi yang sudah tertata dengan baik, dengan rekaman rekrutmen karyawan yang cukup panjang maka manajer bisa dengan mudah menempatkan seorang karyawan di perbankan syariah sampang madura. Posisi di kantor cabang memang tidak selengkap yang ada dipusat maupun regional officer sehingga hal itu mempermudah menematkan seseorang disebuah posisi tertentu.

\section{Daftar Pustaka}

Bogdan, Robert \& Steven J. Taylor. 1993. Kualitatif; dasar-dasar Penelitia, terj. Khozin Afandi. Surabaya: Usaha Nasional,.

Bungin, Burhan. 2006. Penelitian Kualitatif Komunikasi, Ekonomi, Kebijakan Publik dan Ilmu Sosial lainnya (jakarta: Prenada Media Group,. 
Corbin, Anselm Strauss Juliet. 1997. Dasar-Dasar Penelitian kualitatif Prosedur, Teknik dan Teori Grounded, terj. M. Djunaidi. Surabaya: Bina Ilmu.

Dey, Ian. 1993. Qualtative Data Analysis a User-Friendley Guide for Social Scientist . London: Routledge.

http://www.landasanteori.com/2015/10/pengertian-profesionalisme-kerja.html. di akses tanggal 4 April 2017.

http://jurnal.uinsu.ac.id/index.php/analytica/article/view/477, di akses tanggal 2 April 2017.

http://jurnal.fkip.uns.ac.id/index.php/ekonomi/article/view/4181, di akses tanggal 2 April 2017.

http://journal.binus.ac.id/index.php/BBR/article/view/989, di akses tanggal 2 April 2017.

http://ib.ui.ac.id/file?file=digital/20306049-T30958\%20- \%20Kajian\%20pengaruh.pdf.,di akses tanggal 2 April 2017.

Kuntowijoyo. 2002. Social Cahnge in an Agriculture Society: Madura 18501940. Universitas Columbia New York. Terj. M. Effedndi dan P. Amaripuja, Perubahan Sosial dalam Masyarakat Agraris. Madura 1850-1940. Yogyakarta: Matabangsa.

Martono, Nanang. 2015. Metode Penelitian Sosial; Konsp-Konsep Kunci. Jakarta: RajaWali Press.

Moutakas, Lark. 1994. Phenomenological Research Methods. Calfornia: SAGE, Thousand Oaks.

Muhammad. 2016. Manajemen Pembiayaan Bank Syariah. Yogyakarta:UPP STIM YKPN.

Nawawi, Ismai'il. 2002. Ekonomi Mikro Dalam Perspektif Islam. Surabaya: ITS Press.

Nawawi, Ismai'il. 2013. Isu-Isu Ekonomi Islam. Jakarta: Dwi Putra Pustaka Jaya.

Nawawi, Ismai'il. 2011. Islam dan Bisnis; Pendekatan Ekonomi dan Manajemen; Doktrin, Teori dan Praktik. Surabaya: VIVPress.

Rifa'i, Mien Ahmad. 2007. Manusia Madura. Jakrta:Pilar Media.

Saifuddin, Ahmad Fedyani.2005. Antropologi Kontemporer Suatu Pengantar Kritis Mengenai Paradigma. Jakarta: Prenada Media.

Sigit, Soeharto. 1999. Pengantar Metodologi Penelitian Sosial-Bisnis-Manajemen. Jakarta: Lukman Offset.

Soeparto, Sri. Fenomenologi Husser sebagai dasar Mengembangkan Filsafat dan Dasar Menetukan Kebenaran, Jurnal Filsafat. Yogyakarta: Yayasan Pembina Fakultas Filsafat UGM seri ke-30 Oktober 1999.

Wijaya Taufiq, Budi Sukardi. Corporate Ethical Identity Perbankan Syariah di Indonesia. Tsaqafah 9.2 (2013): 337-356., 